\title{
Indel-II region deletion sizes in the white spot syndrome virus genome correlate with shrimp disease outbreaks in southern Vietnam
}

\author{
Tran Thi Tuyet Hoa ${ }^{1,2,3}$, Mark P. Zwart ${ }^{4}$, Nguyen T. Phuong ${ }^{2}$, Dang T. H. Oanh ${ }^{2}$, \\ Mart C. M. de Jong ${ }^{3}$, Just M. Vlak ${ }^{1, *}$
}

${ }^{1}$ Laboratory of Virology, Wageningen University, Droevendaalsesteeg 1, 6708 PB Wageningen, The Netherlands

${ }^{2}$ College of Aquaculture and Fisheries, Can Tho University, Campus II, 3/2 street, Can Tho City, Vietnam ${ }^{3}$ Quantitative Veterinary Epidemiology, Wageningen University, Marijkeweg 40, 6709 PG Wageningen, The Netherlands ${ }^{4}$ Instituto de Biología Molecular y Celular de Plantas, Consejo Superior de Investigaciones Científicas-UPV, Valencia, Spain

\begin{abstract}
Sequence comparisons of the genomes of white spot syndrome virus (WSSV) strains have identified regions containing variable-length insertions/deletions (i.e. indels). Indel-I and Indel-II, positioned between open reading frames (ORFs) 14/15 and 23/24, respectively, are the largest and the most variable. Here we examined the nature of these 2 indel regions in 313 WSSVinfected Penaeus monodon shrimp collected between 2006 and 2009 from 76 aquaculture ponds in the Mekong Delta region of Vietnam. In the Indel-I region, 2 WSSV genotypes with deletions of either 5950 or $6031 \mathrm{bp}$ in length compared with that of a reference strain from Thailand (WSSVTH-96-II) were detected. In the Indel-II region, 4 WSSV genotypes with deletions of 8539, 10970 , 11049 or $11866 \mathrm{bp}$ in length compared with that of a reference strain from Taiwan (WSSV-TW) were detected, and the 8539 and 10970 bp genotypes predominated. Indel-II variants with longer deletions were found to correlate statistically with WSSV-diseased shrimp originating from more intensive farming systems. Like Indel-I lengths, Indel-II lengths also varied based on the Mekong Delta province from which farmed shrimp were collected.
\end{abstract}

KEY WORDS: White spot syndrome virus · Disease status · Farming system · Epidemiology · ORF 14/15 - ORF $23 / 24$

Resale or republication not permitted without written consent of the publisher

\section{INTRODUCTION}

White spot syndrome virus (WSSV) is one of the most widely distributed of all known viruses of aquatic crustaceans. The first outbreaks of white spot disease (WSD) were reported in 1992 in Taiwan and China (Chou et al. 1995, Huang et al. 1995). The disease quickly spread to Japan and Korea (Inouye et al. 1994, Kim et al. 1998), then to countries throughout southeast Asia and the Indian continent as well as to Central and South America (Escobedo-Bonilla et al. 2008). Recently, WSSV has been detected in shrimp farmed in southeast Europe and the Middle East (OIE
2009, Lightner 2011). Comparisons of WSSV strains examined at different times from different geographical locations have revealed similarities in disease symptoms and histopathology (Flegel 1997, Wang et al. 1999, Leu et al. 2009), but differences in virus morphology (Leu et al. 2009), genome structure (Marks et al. 2004, Shekar et al. 2005) and virulence (Marks et al. 2005, Zwart et al. 2010). Except for 2 genome regions in which major insertions/deletions (indels) occur, 9 regions containing homologous repeats and 3 regions containing variable-number tandem repeat (VNTR) sequences, the genome nucleotide sequences of different WSSV strains are 
highly (>99.5\%) conserved (Nadala \& Loh 1998, Marks et al. 2004).

The 2 major genomic indels are located between open reading frames (ORFs) 14/15 (Indel-I) and 23/24 (Indel-II) of the sequenced Thai strain WSSVTH-96-I (van Hulten et al. 2001, Marks et al. 2004, 2005). Compared with another sequenced Thai strain (WSSV-TH-96-II), WSSV-TH-96-I has a $5.3 \mathrm{~kb}$ deletion in Indel-I (Marks et al. 2005) and differs from a strain from Taiwan (WSSV-TW) by possessing a $13.2 \mathrm{~kb}$ deletion in Indel-II (Marks et al. 2004). Sequence analyses of these 2 indel regions in other Asian WSSV strains have identified intermediatelength deletions (Dieu et al. 2004, 2010, Zwart et al. 2010). For example, WSSV strains from China contain shorter Indel-II deletions (1168 to 5928 bp) compared with WSSV-TW, while strains from Vietnam contain a medium-length Indel-II deletion ( $8539 \mathrm{bp})$ not yet found in strains examined from other geographic regions (Dieu et al. 2004; see also Yang et al. 2001, Lan et al. 2002, Tan \& Shi 2011).

Indel-I and Indel-II regions are now being used as molecular markers to study WSSV epidemiology (Dieu et al. 2004, 2010, Zwart et al. 2010), and IndelII is proving to be particularly useful for examining the spatiotemporal spread of WSSV at regional (Dieu et al. 2010) and intercontinental levels (Zwart et al. 2010). Data on Indel-II support a hypothesis that all WSSV strains affecting farmed shrimp have a recent common ancestor. This virus presumably circulated in China or Taiwan before spreading to shrimp farms in Vietnam, from there to Thailand (Dieu et al. 2004) and from there to India (Pradeep et al. 2008a) and other Asian countries (Zwart et al. 2010). However, as a WSSV strain originating from Thailand in 1996 (WSSV-TH-96-II) possesses the longest genome of all strains characterized to date (Marks et al. 2005), it is possible that WSSV might have been introduced initially into China and/or Taiwan through imports of live shrimp from Thailand.

VNTRs have been used to study WSSV epidemiology in different crustacean hosts at small (farm or pond) spatiotemporal scales (Wongteerasupaya et al. 2003, Hoa et al. 2005, Pradeep et al. 2008b) to detect mixed WSSV infections in shrimp (Hoa et al. 2011a) and to examine WSSV transmission within and between aquaculture ponds (Pradeep et al. 2008b, Walker et al. 2011). Data on VNTRs in conjunction with epidemiological models have also been used to quantify different transmission routes of WSSV within and between farm ponds (Hoa et al. 2011b).

In a preliminary longitudinal study of WSSV genotypes affecting farmed shrimp, the Indel-II region was useful for tracking genotypes over time (Dieu et al. 2011). WSSV genome lengths estimated from analyses of Indel-I and Indel-II lengths suggest that genome shrinkage rates since 1992 are decreasing over time (Zwart et al. 2010). While increased Indel-I and Indel-II deletion lengths have been associated with increased WSSV virulence (Marks et al. 2005, Zwart et al. 2010), an early study reported reduced virulence with increased Indel-II deletion lengths (Lan et al. 2002).

Here we report on a spatiotemporal study examining Indel-I and Indel-II deletion lengths in WSSV strains detected in Penaeus monodon shrimp collected between 2006 and 2009 from different farm types in 2 regions of the Mekong Delta in Vietnam. The data associated increased Indel-II deletion lengths with WSSV disease and thus with higher intensity farming systems from which most diseased shrimp were collected over the study period.

\section{MATERIALS AND METHODS}

\section{Shrimp samples and classification of farming system}

In total, 313 WSSV-infected Penaeus monodon collected from 35 aquaculture ponds in Bac Lieu province and 41 ponds in Ca Mau province, Mekong Delta, Vietnam, in 2006, 2008 and 2009 were examined. Shrimp were sampled either at time of stocking $(n=140)$ or at the time of disease outbreaks when ponds were emergency harvested $(n=173)$. Whole shrimp were stored either in $100 \%$ ethanol at room temperature or in liquid nitrogen before being transferred to $-80^{\circ} \mathrm{C}$.

Farm management systems from which shrimp were collected were classified as either improvedextensive, rice-shrimp or semi-intensive. Improvedextensive farms primarily recruit wild Penaeus monodon postlarvae (PL) and juveniles, but sometimes supplement these with PL from hatcheries. Riceshrimp farms tend to be stocked at low densities (0.5 to $2 \mathrm{PL} \mathrm{m}^{-2}$ ), have shrimp at different developmental stages, use little or no feed and only operate during the dry season when paddies are not being used to grow rice. Semi-intensive farms tend to use aerated ponds that are drained and cleaned before stocking, hatchery PL seeded at higher stocking densities (12 to $20 \mathrm{PL} \mathrm{m}^{-2}$ ) and industrial shrimp feed. Shrimp were sampled from 41 improved-extensive ponds (37 in Ca Mau province and 4 in Bac Lieu province), 27 semi-intensive ponds ( 4 in Ca Mau and 23 in Bac Lieu) and 8 rice-shrimp plots (all in Bac Lieu). The 
farming systems from which shrimp were sampled in Ca Mau and Bac Lieu provinces were quite distinct $\left(\chi^{2}=227.40, \mathrm{df}=2, \mathrm{p}<0.001\right)$ (Table 1$)$. In reality there are also differences in the farm systems used in these 2 provinces; there are relatively more semiintensive ponds and rice-shrimp plots in Bac Lieu than in Ca Mau, and relatively fewer improved-extensive ponds in Bac Lieu than in Ca Mau (Anonymous 2009).

\section{WSSV PCR}

WSSV DNA was extracted from gill tissues and amplified by 2-step PCR using the IQ2000 ${ }^{\mathrm{TM}}$ WSSV kit (GeneReach Biotechnology) according to the manufacturer's instructions. The primer sets were designed to amplify WSSV-specific products 296 and/or 550 bp in length, as well as an 848 bp crustacean-specific product to confirm the integrity of the DNA.

Table 1. Number (and percent) of farms associated with shrimp farming types with provinces in the Mekong Delta, Vietnam. Pearson's chi-squared test indicates a significant correlation between province and farming type $(p<0.001)$

\begin{tabular}{|c|c|c|}
\hline Shrimp source & $\begin{array}{l}\text { Ca Mau pro- } \\
\text { vince } n(\%)\end{array}$ & $\begin{array}{l}\text { Bac Lieu pro- } \\
\text { vince } n(\%)\end{array}$ \\
\hline Improved-extensive ponds & $162(96 \%)$ & $7(4 \%)$ \\
\hline Semi-intensive ponds & $17(16 \%)$ & $88(84 \%)$ \\
\hline Rice-shrimp plots & $0(0 \%)$ & $39(100 \%)$ \\
\hline
\end{tabular}

\section{PCR amplification across WSSV indels}

WSSV Indel-I and Indel-II regions were amplified by PCR using the primer sets VR14/15-screen, VR23/24-screen, VR23/24-1 and VR23/24-south (adapted from Dieu et al. 2004, 2010) and 14/15-complete (adapted from Marks et al. 2005) (Table 2). Approximate $200 \mathrm{ng}$ DNA was amplified in a $25 \mu \mathrm{l}$ reaction containing $\mathrm{PCR}$ master mix (Promega) using the thermal cycling conditions of $94^{\circ} \mathrm{C}$ for $5 \mathrm{~min}$, 30 cycles of $94^{\circ} \mathrm{C}$ for $30 \mathrm{~s}, 49$ to $55^{\circ} \mathrm{C}$ (primer dependent) for $30 \mathrm{~s}$ and $72^{\circ} \mathrm{C}$ for up to $7 \mathrm{~min}$ depending on the expected amplicon length. PCR products were resolved in $1 \%$ agarose gels beside a 100 bp Plus DNA marker (Fermentas).

\section{PCR product sequence analysis}

Representative PCR products were sequenced to confirm that indel lengths had been estimated accurately. PCR products were purified by using the GFX PCR DNA and Gel Band Purification kit (GE Healthcare) and sequenced by Macrogen (Seoul, South Korea). Sequence chromatograms were examined by using Chromas v. 1.45 and edited with BioEdit 7.0.9 (Hall 1999). BLASTn was used to align Indel-I and Indel-II sequences to the reference WSSV strains WSSV-TH-96-II (AY753327) and WSSV-TW (AF440570) as well as to other available WSSV sequences (AF369029, AF332093).

Table 2. Sequences of PCR primers used to amplify WSSV Indel-I and Indel-II regions. F: forward; R: reverse

\begin{tabular}{|c|c|c|c|c|c|}
\hline Primer set name & Sequence $\left(5^{\prime}\right.$ to $\left.3^{\prime}\right)$ & $\begin{array}{l}\text { Annealing } \\
\text { temper- } \\
\text { ature } \\
\left({ }^{\circ} \mathrm{C}\right)\end{array}$ & $\begin{array}{l}\text { Elong- } \\
\text { ation } \\
\text { time } \\
\text { (s) }\end{array}$ & $\begin{array}{l}\text { WSSV-TW } \\
\text { nucleotide sequence } \\
\text { coordinates of the } \\
\text { region amplified }\end{array}$ & Reference \\
\hline \multicolumn{6}{|l|}{ Indel-I } \\
\hline VR14/15-screen (F) & GAGATGCGAACCACTAAAAG & \multirow[t]{2}{*}{49} & \multirow[t]{2}{*}{75} & 301765-301784 & \multirow[t]{2}{*}{ Dieu et al. (2004) } \\
\hline VR14/15-screen (R) & ATGGAGGCGAGACTTGC & & & 303179-303195 & \\
\hline 14/15-complete (F) & AATATGGAACGACGGGTG & \multirow[t]{2}{*}{55} & \multirow[t]{2}{*}{420} & 301090-301107 & \multirow[t]{2}{*}{ Marks et al. (2005 } \\
\hline 14/15-complete (R) & GACCAGCGCСТCTTCAG & & & $303735-303751$ & \\
\hline \multicolumn{6}{|l|}{ Indel-II } \\
\hline VR23/24-screen (F) & CACACTTGAAAAATACACCAG & \multirow[t]{2}{*}{49} & \multirow[t]{2}{*}{65} & $5503-5523$ & \multirow[t]{2}{*}{ Dieu et al. (2004) } \\
\hline VR23/24-screen (R) & GTAAGTTTATTGCTGAGAAG & & & $14571-14590$ & \\
\hline VR23/24-1(F) & ATGGGCTCTGCTAACTTG & \multirow[t]{2}{*}{50} & \multirow[t]{2}{*}{360} & $4359-4376$ & \multirow[t]{2}{*}{ Dieu et al. (2004) } \\
\hline VR23/24-1 (R) & ATGATTGTATTCGTCGAAGG & & & $15172-15191$ & \\
\hline VR23/24-south (F) & GTAGTGCATGTTTCTCTAAC & \multirow[t]{2}{*}{49} & \multirow[t]{2}{*}{100} & $2356-2375$ & \multirow[t]{2}{*}{ Dieu et al. (2010) } \\
\hline VR23/24-south (R) & GTAAGTTTATTGCTGAGAAG & & & $14571-14590$ & \\
\hline
\end{tabular}




\section{Statistical analysis}

Indel lengths were coded as small (5950 bp for Indel-I and $8539 \mathrm{bp}$ for Indel-II) or large (6031 bp for Indel-I and 10970-11866 bp for Indel-II). A $2 \times 2$ contingency table was constructed by counting the numbers of each WSSV indel type with disease status or sampling location of each shrimp, and a $2 \times 3$ contingency table was constructed by counting the numbers of each WSSV indel types and the farming system from which each shrimp was collected. The relationship between farming system or disease status and Indel-I or Indel-II type detected was quantified by using Pearson's chi-squared test. All probability tests were right sided with a significance level of 0.05 .

\section{RESULTS}

\section{WSSV Indel-I variants in shrimp from Ca Mau and Bac Lieu provinces}

WSSV ORF 14/15 Indel-I lengths were determined for 313 shrimp that tested positive in the WSSV IQ2000 ${ }^{\mathrm{TM}}$ PCR (Fig. 1). Among the 2 Indel-I PCR primer sets used, set VR14/15-screen amplified products for 159 of 214 samples tested and set 14/15-complete amplified products for 15 of 38 samples tested. Sequence analyses confirmed that products amplified by either primer set represented 5950 or 6031 bp deletion types (Fig. 2A) compared with the reference
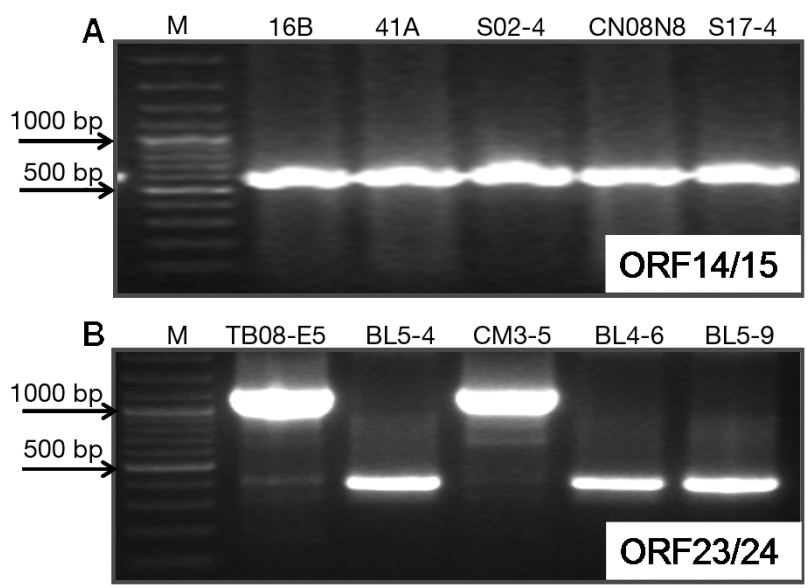

Fig. 1. Penaeus monodon. An agarose gel showing WSSVspecific PCR products amplified from individual shrimp (various identification codes) using either (A) primer set VR14/15-screen (600 bp) for Indel-I or (B) primer set VR23/24-south (400 or $1200 \mathrm{bp}$ ) for Indel-II. M: DNA marker strain containing the maximum-length indel sequence, Thai strain WSSV-TH-96-II (Dieu et al. 2004, Marks et al. 2004). Statistical analyses determined that neither Indel-I deletion type was correlated with the improved-extensive, rice-shrimp or semiintensive farming system from which the shrimp originated $\left(\chi^{2}=2.38\right.$, df $\left.=2, p=0.305\right)$, or whether shrimp were healthy or diseased $\left(\chi^{2}=0.85, \mathrm{df}=1, \mathrm{p}=\right.$ $0.358)$, but that Indel-I types segregated based on the Ca Mau or Bac Lieu provinces from which shrimp were collected $\left(\chi^{2}=13.15\right.$, df $\left.=1, p<0.001\right)$ (see Table 6).

\section{WSSV Indel-II variants in shrimp from Ca Mau and Bac Lieu provinces}

The various PCR primer sets used were only able to determine ORF 23/24 Indel-II lengths for 206 of the 313 WSSV-positive samples tested. For the others, either no PCR product was amplified or multiple PCR products were amplified that could not be distinguished clearly. PCR primer set VR23/24-screen failed to amplify a product of the expected size (548 bp; Dieu et al. 2004) from any WSSV-positive shrimp. Set VR23/24-1 amplified a $\sim 2.3 \mathrm{~kb}$ product from 109 of 216 shrimp that was confirmed by sequence analysis to contain a 8539 bp deletion (Indel-II nucleotide region 5793-14332) compared with the reference strain containing the maximumlength indel sequence, Taiwanese strain WSSV-TW (Marks et al. 2004). Of 119 samples amplified by using primer set VR23/24-south, 97 generated products either $\sim 400$ and/or $\sim 1200$ bp in length (Fig. 1). These were confirmed by sequence analysis to possess Indel-II deletions 11866 bp $(\mathrm{n}=4), 10970$ bp ( $\mathrm{n}=$ $70)$ or both $(\mathrm{n}=22)$ (Indel-II nucleotide regions $2704-$ 14570 or $3372-14342$ ), or 11049 bp (n = 1) (Indel-II nucleotide region 3387-14436) in length compared with WSSV-TW (Table 3).

Of the putative proteins encoded within the $13 \mathrm{~kb}$ Indel-II region of WSSV-TW, two (wSSv006 and wSSV025) are retained even in those genotypes identified to contain the longest (11866 bp) deletion (Table 4, Fig. 2B). These ORFs reside adjacent to an essential early viral gene, wssv004 (Han et al. 2007) and do not exist in the virulent Thai strain WSSV-TH-96-I or other Asian strains detected more recently in WSSVdiseased shrimp (Zwart et al. 2010). Characteristics of WSSV proteins in this region predicted from in silico analyses, including nonessential transmembrane protein wsv479 that can be found in virions (Yang et al. 2001), are summarized in Table 4. 

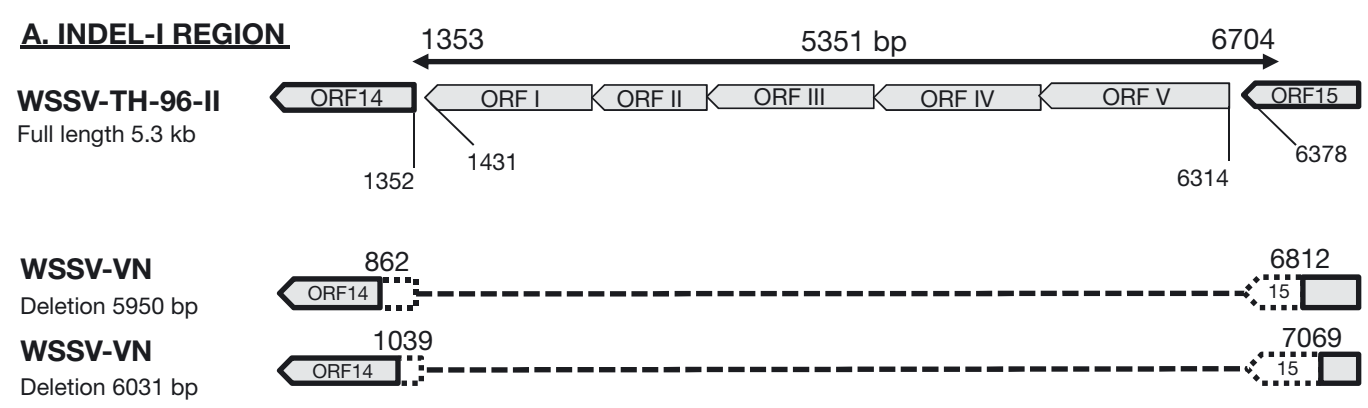

\section{B. INDEL-II REGION}

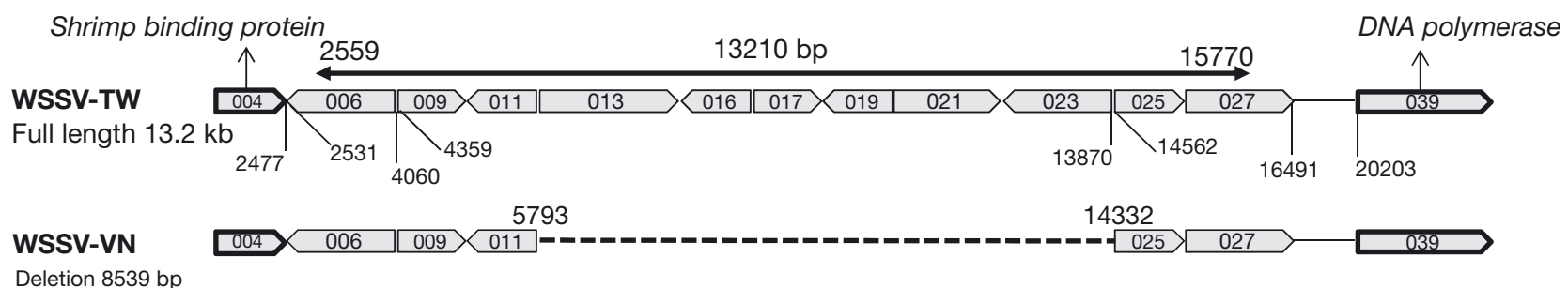

Deletion 8539 bp

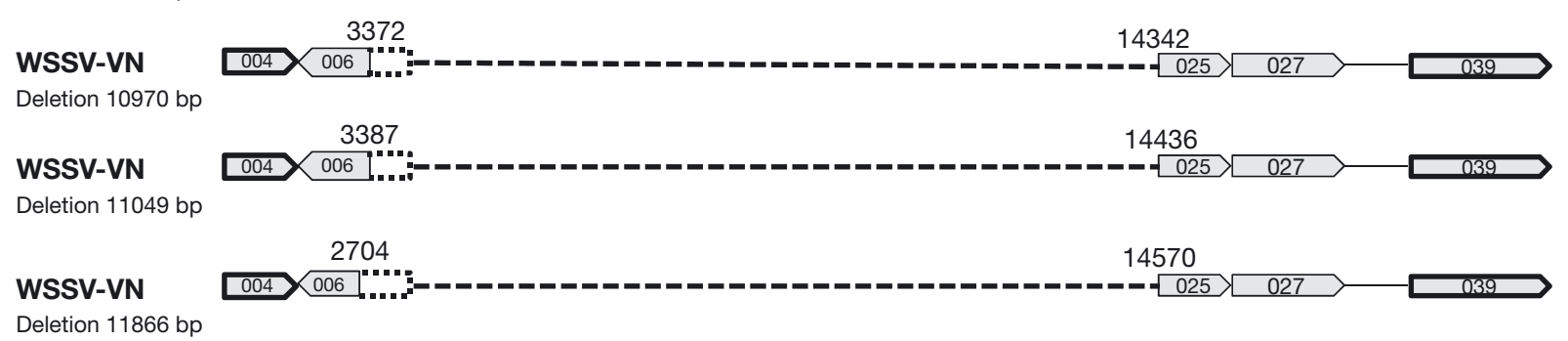

Fig. 2. Penaeus monodon. (A) Schematic representation of the Indel-I region of the putative ancestral WSSV strain WSSV-TH96-II (1353-6704), which contains the longest known Indel-I region (Marks et al. 2005) and 2 representative WSSV-VN strains detected in shrimp sampled from the Mekong Delta, Vietnam. The numbers indicate genome nucleotide positions in WSSVTH-96-II (AY753327), and dashed lines represent deleted sequences. (B) Schematic representation of the Indel-II region of the putative ancestral WSSV strain WSSV-TW (2559-15770), which contains the longest known Indel-II region, and 4 representative WSSV-VN strains. The numbers indicate genome nucleotide positions in WSSV-TW (AF440570) and dashed lines represent deleted sequences

\section{Relationship between WSSV Indel-II type, disease, farm systems and location}

Contingency tables were constructed to determine whether Indel-II deletion type might correlate with WSSV disease status, farming system and farm location. However, as (1) farming systems used in the 2 Mekong Delta provinces studied vary in number (Anonymous 2009), (2) emergency harvests owing to WSSV disease outbreaks will mostly occur in more stringently managed semi-intensive farm systems and (3) samples were not collected specifically to examine these variables, correlations among them or to Indel-II types need to be interpreted with caution at best. Of the 313 WSSV PCR-positive shrimp examined, 173 were collected from 33 ponds at the time of stocking when there was no evidence of disease and 140 shrimp were collected from 43 ponds at times of emergency harvesting owing to outbreaks of WSSV disease. Of the Indel-II types detected in 206 of these 313 shrimp (Table 5), the 10970 bp deletion was detected in 65 of the 159 (41\%) diseased shrimp and in 5 of the 47 (11\%) healthy shrimp. When grouped into either shorter (8539 bp) or longer Indel-II deletion (10970-11866 bp) types, a $2 \times 2$ contingency table showed longer deletion types to be correlated significantly with WSSV disease $\left(\chi^{2}=5.63, \mathrm{df}=1, \mathrm{p}=\right.$ 0.018) (Table 6).

Indel-II deletion types were assessed similarly as to whether shrimp had originated from rice-shrimp plots $(n=37)$, improved-extensive ponds $(n=74)$ or semi-intensive ponds ( $\mathrm{n}=95$ ) (Table 5). The $8539 \mathrm{bp}$ Indel-II deletion type occurred in all 37 shrimp from rice-shrimp plots and 50 of the 74 (68\%) shrimp from improved-extensive ponds. The $10970 \mathrm{bp}$ Indel-II deletion type occurred in 64 of the 95 (67\%) shrimp from semi-intensive ponds. Mixed Indel-II deletion types were detected in 13 of the $74(18 \%)$ shrimp 
Table 3. Indel-I and Indel-II deletion lengths identified among WSSV strains analyzed here and in other studies. Numbers in bold text indicate deletion lengths found both here and in other studies. Indel-I values are compared with WSSVTH-96-II sequence (AY753327); Indel-II values are compared with WSSV-TW sequence (AF440570). nd: not determined or no PCR product amplified

\begin{tabular}{|c|c|c|c|c|}
\hline $\begin{array}{l}\text { Country and } \\
\text { WSSV strain }\end{array}$ & $\begin{array}{l}\text { Deletion } \\
\text { Indel-I }\end{array}$ & $\begin{array}{l}\text { ength (bp) } \\
\text { Indel-II }\end{array}$ & $\begin{array}{l}\text { Position } \\
\text { Indel-II }\end{array}$ & Reference \\
\hline \multicolumn{5}{|l|}{ Thailand } \\
\hline WSSV-TH & 5316 & 13210 & $2559-15770$ & $\begin{array}{l}\text { van Hulten et al. } \\
\text { (2001) }\end{array}$ \\
\hline \multicolumn{5}{|l|}{ China } \\
\hline WSSV-CN & 5131 & 11682 & 283412-283413 & Yang et al. (2001) \\
\hline WSSV-CN-A & nd & $5717 \quad 2$ & 281048-285596 & Lan et al. (2002) \\
\hline WSSV-CN-B & nd & $5926 \quad 2$ & $281048-285805$ & Lan et al. (2002) \\
\hline WSSV-CN-C & & 93192 & $277564-285716$ & Lan et al. (2002) \\
\hline WSSV98NB2 & 4749 & 110932 & 275879-285805 & Tan \& Shi (2011) \\
\hline \multicolumn{5}{|l|}{ Brazil } \\
\hline WSSV-Brazil & nd & 11453 & 2719-14172 & Muller et al. (2010) \\
\hline \multicolumn{5}{|l|}{ India } \\
\hline WSSV-India & 5892 & 10970 & $3372-14342$ & $\begin{array}{l}\text { Pradeep et al. } \\
(2008 \mathrm{a})\end{array}$ \\
\hline \multicolumn{5}{|l|}{ Vietnam } \\
\hline WSSV-VN-Central & 5950 & 8539 & 5793-14333 & Dieu et al. (2004) \\
\hline WSSV-ND-North & 6031 & 9631 & $4860-14493$ & Dieu et al. (2010) \\
\hline WSSV-HP-North & 6031 & 11048 & $3342-14342$ & Dieu et al. (2010) \\
\hline WSSV-LA-South & 5950 & 10970 & $3372-14342$ & Zwart et al. (2010) \\
\hline WSSV-TV-South & 6031 & 11450 & 2858-14309 & Dieu et al. (2004) \\
\hline WSSV-HT-South & 5138 & 11886 & $2704-14570$ & Dieu et al. (2010) \\
\hline WSSV-KG-South & 6031 & 12166 & 3099-15266 & Dieu et al. (2004) \\
\hline WSSV-BR-South & 5316 & 13210 & $2559-15770$ & Dieu et al. (2010) \\
\hline \multicolumn{5}{|l|}{ South Vietnam } \\
\hline VN-Extensive-CN08N5 & $5 \quad 5950$ & nd & & Present study \\
\hline VN-Extensive-TB08B4 & nd & 10970 & $3372-14342$ & Present study \\
\hline VN-Extensive-CM7.8.1 & nd & 11049 & $3387-14436$ & Present study \\
\hline $\begin{array}{c}\text { VN-Extensive- } \\
\text { TB08-M20 }\end{array}$ & 5950 & 10970 & $3372-14342$ & Present study \\
\hline VN-Intensive-CM3.5.13 & 3 nd & 10970 & $3372-14342$ & Present study \\
\hline VN-Intensive-CM3.5.14 & 4 nd & 10970 & $3372-14342$ & Present study \\
\hline VN-Intensive-17A & 6031 & 8539 & $5793-14332$ & Present study \\
\hline VN-Intensive-31A & 5950 & 10970 & $3372-14342$ & Present study \\
\hline VN-Intensive-S9.1 & nd & 10970 & $3371-14342$ & Present study \\
\hline VN-Intensive-S20.2 & 5950 & 10970 & $3372-14342$ & Present study \\
\hline VN-Intensive-S15 & 5950 & nd & & Present study \\
\hline VN-Intensive-S26 & 5950 & 10970 & $3372-14342$ & Present study \\
\hline
\end{tabular}

Lieu province but only 7 of the $80(9 \%)$ shrimp from Ca Mau province. A $2 \times 2$ contingency table constructed with these data showed Indel-II types to differ significantly based on the province from which shrimp were collected $\left(\chi^{2}=28.59\right.$, $\mathrm{df}=1, \mathrm{p}<0.001$ ) (Table 6).

\section{DISCUSSION}

Genomic indels and VNTR sequences are being used increasingly as epidemiological tools to predict disease and trace the spread of WSSV to different shrimp farming regions within and beyond Asia, including the western hemisphere (Dieu et al. 2004, Pradeep et al. 2008a, Muller et al. 2010). For example, certain repeat structures in ORF 125 and particularly in ORF 94 have been found to correlate with disease outbreaks (Dieu et al. 2011, Hoa et al. 2011b). Although no specific repeat unit (RU) numbers have been associated with particular farming systems (Hoa et al. 2012), WSSV types in shrimp reared in extensive systems appear to remain more stable than in shrimp reared in semi-intensive systems (Dieu et al. 2011, Hoa et al. 2011b). These findings may contribute to our understanding of how WSSV population structures influence disease.

To examine whether different WSSV indel variants might correlate with disease status, location

from improved-extensive ponds and in 9 of the 95 $(10 \%)$ shrimp from semi-intensive ponds. Construction of a $2 \times 3$ contingency table showed that the shortest (8539 bp) Indel-II deletion type was correlated significantly with shrimp sampled from improved-extensive ponds and rice-shrimp plots $\left(\chi^{2}=73.06, \mathrm{df}=2, \mathrm{p}<0.001\right)$ (Table 6).

The $8539 \mathrm{bp}$ Indel-II deletion was detected in 61 of the $80(76 \%)$ shrimp collected from Ca Mau province and 48 of the 126 (38\%) collected from Bac Lieu province. In contrast, the 10970 bp Indel-II deletion was detected in 63 of the 126 (50\%) shrimp from Bac and system used to farm Penaeus monodon in the Mekong Delta region of Vietnam, shrimp were sampled over a $3 \mathrm{yr}$ period at times of pond stocking and when they were emergency harvested owing to WSSV disease occurring. For Indel-I within the WSSV ORF 14/15 region, deletions of 5950 or $6031 \mathrm{bp}$ were detected as found previously among WSSV strains infecting shrimp farmed in central and southern regions of Vietnam (Dieu et al. 2004, 2010). These indel types appear to be quite stable and unique to WSSV strains in Vietnam, but have not been found to be associated with disease or farm sys- 
Table 4. Characteristics of Indel-II deletions in WSSV reference strains and those detected in Mekong Delta shrimp Penaeus monodon. $\mathrm{X}$ indicates an open reading frame (ORF) has been deleted; ZF indicates a Cys2/Cys2-type zinc finger is present and TM indicates a putative transmembrane protein. Italics indicate ORF was embedded in the ORF shown in bold above; bold indicates deletion lengths found both here and in other studies. References are indicated by superscript letters and given as footnotes

\begin{tabular}{|c|c|c|c|c|c|c|c|c|}
\hline $\begin{array}{l}\text { ORFs ence } \\
\text { WSSV- } \\
\text { Taiwan }\end{array}$ & $\begin{array}{l}\text { ded } \\
\text { WSSV- } \\
\text { China }\end{array}$ & Characteristic & $\begin{array}{c}\text { TH-I-96 } \\
\text { and } \\
\text { VN-BR }^{\mathrm{b}} \\
(13210 \mathrm{bp})\end{array}$ & $\begin{array}{l}\text { TH-II- } \\
96^{\mathrm{c}} \\
(0 \mathrm{bp})\end{array}$ & $\begin{array}{c}\text { IN and } \\
\text { VN-LA } \\
\text { VN }^{\mathrm{e}} \\
(10970 \mathrm{bp})\end{array}$ & $\begin{array}{l}\mathrm{VN} \mathrm{ST}^{\mathrm{b}} \\
\mathrm{VN}^{\mathrm{e}} \\
(11866 \mathrm{bp})\end{array}$ & $\begin{array}{c}\mathrm{VN}^{\mathrm{f}} \\
\mathrm{VN}^{\mathrm{e}} \\
(8539 \mathrm{bp})\end{array}$ & $\begin{array}{c}\mathrm{VN}^{\mathrm{e}} \\
(11049 \mathrm{bp})\end{array}$ \\
\hline wsSv004 & wSv477 & Protein interaction with host actin ${ }^{\mathrm{g}, \mathrm{h}}$ & ORF 23 & & & & & \\
\hline WSSV005 & wsv478 & $\begin{array}{l}\text { Early gene and GTP-binding motif }{ }^{\mathrm{i}} \\
\mathrm{ZF}^{\mathrm{h}}, \mathrm{TM}\end{array}$ & & & & & & \\
\hline wsSv006 & wsv479 & Expression at $12 \mathrm{hpi}^{\mathrm{h}}$ & $\mathrm{X}$ & & & & & \\
\hline WSSV007 & WSV480 & $\mathrm{TM}^{\mathrm{h}}$, Glu-rich cluster & & & & $\mathrm{X}$ & & \\
\hline wSSv008 & wsv481 & & $\mathrm{X}$ & & $\mathrm{X}$ & $\mathrm{X}$ & & $\mathrm{X}$ \\
\hline wSSv009 & wsv482 & $\mathrm{TM}^{\mathrm{h}}$ & $\mathrm{X}$ & & $\mathrm{X}$ & $\mathrm{X}$ & & $\mathrm{X}$ \\
\hline WSSv010 & wsv483 & & $\mathrm{X}$ & & $\mathrm{X}$ & $\mathrm{X}$ & & $\mathrm{X}$ \\
\hline wsSv011 & wsv484 & $\mathrm{TM}^{\mathrm{h}}$ & $\mathrm{X}$ & & $\mathrm{X}$ & $\mathrm{X}$ & & $\mathrm{X}$ \\
\hline wssv012 & wsv485 & & & & & & & \\
\hline wssv013 & wsv486 & $\mathrm{TM}^{\mathrm{h}}$ & $\mathrm{X}$ & & $\mathrm{X}$ & $\mathrm{X}$ & $\mathrm{X}$ & $\mathrm{X}$ \\
\hline wsSv014 & wsv487 & & $\mathrm{X}$ & & $\mathrm{X}$ & $\mathrm{X}$ & $\mathrm{X}$ & $\mathrm{X}$ \\
\hline wsSV015 & wsv488 & & & & & & & \\
\hline wSSv016 & wSv489 & & $\mathrm{X}$ & & $\mathrm{X}$ & $\mathrm{X}$ & $\mathrm{X}$ & $\mathrm{X}$ \\
\hline WSSv017 & wsv492 & & $\mathrm{X}$ & & $\mathrm{X}$ & $\mathrm{X}$ & $\mathrm{X}$ & $\mathrm{X}$ \\
\hline WSSV018 & wsv491 & & & & & & & \\
\hline wssv019 & wsv493 & Viral envelope protein $(\mathrm{vp} 35)^{\mathrm{j}}$ & $\mathrm{X}$ & & $\mathrm{X}$ & $\mathrm{X}$ & $\mathrm{X}$ & $\mathrm{X}$ \\
\hline wssv020 & wSV494 & & $\mathrm{X}$ & & $\mathrm{X}$ & $\mathrm{X}$ & $\mathrm{X}$ & $\mathrm{X}$ \\
\hline wsSv021 & wsv495 & & $\mathrm{X}$ & & $\mathrm{X}$ & $\mathrm{X}$ & $\mathrm{X}$ & $\mathrm{X}$ \\
\hline wssv022 & wsv496 & & $\mathrm{X}$ & & $\mathrm{X}$ & $\mathrm{X}$ & $\mathrm{X}$ & $\mathrm{X}$ \\
\hline wssv023 & wsv497 & $\mathrm{TM}^{\mathrm{h}}$ & $\mathrm{X}$ & & $\mathrm{X}$ & $\mathrm{X}$ & $\mathrm{X}$ & $\mathrm{X}$ \\
\hline WSSV024 & wsv499 & & & & & & & \\
\hline wssv025 & wsv500 & ATP/GTP & $\mathrm{X}$ & & & $\mathrm{X}$ & & $\mathrm{X}$ \\
\hline wssv026 & wsv501 & Binding motif ${ }^{\mathrm{h}}, \mathrm{ZF}^{\mathrm{h}}$ & & & & & & \\
\hline wSSv027 & wsv502 & ATP/GTP binding motif $\mathrm{A}^{\mathrm{h}}$ & ORF 24 & & & & & \\
\hline WSSV028 & wsv503 & $\mathrm{ZF}^{\mathrm{h}}$ & & & & & & \\
\hline WSSV029 & WSV504 & Expression at $18 \mathrm{hpi}^{\mathrm{k}}$ & & & & & & \\
\hline \multirow[t]{2}{*}{ wSSv030 } & & Cell attachment sequence ${ }^{1}, \mathrm{TM}^{\mathrm{h}}$ and & $\mathrm{SP}^{\mathrm{i}}$ & & & & & \\
\hline & wSv508 & $\mathrm{TM}^{\mathrm{h}}$ & ORF 25 & & & & & \\
\hline wssv036 & wsv513 & $\mathrm{TM}^{\mathrm{l}}$ & ORF 26 & & & & & \\
\hline wssv039 & wsv514 & DNA polymerase ${ }^{\mathrm{h}, \mathrm{l}}, \mathrm{TM}^{\mathrm{i}}$ & ORF 27 & & & & & \\
\hline
\end{tabular}

tem or to be useful for distinguishing strain characteristics at regional (Dieu et al. 2010) and intercontinental (Zwart et al. 2010) scales. While the 2 Indel-I types did segregate to either the Ca Mau or Bac Lieu provinces from which shrimp were collected in the Mekong Delta, as nothing is known about the origin of PL seeded into semi-intensive or the other pond types, and as farming systems from which shrimp were sampled from the 2 provinces differed substantially, the significance of this putative geographic segregation of WSSV strains based on Indel-I type will need to be investigated more thoroughly.

For Indel-II in the WSSV ORF 23/24 region, 4 deletion types were detected as found previously among
Penaeus monodon shrimp examined from northern, central and southern regions of Vietnam (Dieu et al. 2004, 2010, Zwart et al. 2010). In these studies, WSSV strains with the $11049 \mathrm{bp}$ deletion type were found in shrimp farmed in northern Vietnam and the 10970 and $11866 \mathrm{bp}$ deletion types were found in shrimp farmed in southern Vietnam. The 10970 bp deletion type, which was found in the present study at high frequency, has also been detected in WSSV strains infecting $P$. monodon shrimp in India (Pradeep et al. 2008a). The $8539 \mathrm{bp}$ deletion type found previously in WSSV strains infecting shrimp farmed in central Vietnam (Dieu et al. 2010) was the most common type detected in the present study among shrimp 
Table 5. Penaeus monodon. Frequency (number and \%) at which WSSV Indel-II deletion types were detected in newly stocked healthy shrimp and in diseased shrimp from emergency harvests from different farming systems across 2 provinces in the Mekong Delta, Vietnam

\begin{tabular}{|c|c|c|c|c|c|}
\hline \multirow{2}{*}{ Shrimp source } & \multicolumn{5}{|c|}{ Indel-II deletion length } \\
\hline & $8539 \mathrm{bp}$ & $10970 \mathrm{bp}$ & $11049 \mathrm{bp}$ & $11866 \mathrm{bp}$ & 10970 and $11866 \mathrm{bp}$ \\
\hline \multicolumn{6}{|l|}{ Farming stage } \\
\hline Emergency harvest & $77(48 \%)$ & $65(41 \%)$ & $0(0 \%)$ & $4(3 \%)$ & $13(8 \%)$ \\
\hline Pond stocking & $32(68 \%)$ & $5(11 \%)$ & $1(2 \%)$ & $0(0 \%)$ & $9(19 \%)$ \\
\hline \multicolumn{6}{|l|}{ Farm type } \\
\hline Improved-extensive ponds & $50(68 \%)$ & $6(8 \%)$ & $1(1 \%)$ & $4(5 \%)$ & $13(18 \%)$ \\
\hline Semi-intensive ponds & $22(23 \%)$ & $64(67 \%)$ & $0(0 \%)$ & $0(0 \%)$ & $9(10 \%)$ \\
\hline Rice-shrimp plots & $37(100 \%)$ & $0(0 \%)$ & $0(0 \%)$ & $0(0 \%)$ & $0(0 \%)$ \\
\hline \multicolumn{6}{|l|}{ Province } \\
\hline Ca Mau province & $61(76 \%)$ & $7(9 \%)$ & $1(1 \%)$ & $0(0 \%)$ & $11(14 \%)$ \\
\hline Bac Lieu province & $48(38 \%)$ & $63(50 \%)$ & $0(0 \%)$ & $4(3 \%)$ & $11(9 \%)$ \\
\hline
\end{tabular}

Table 6. Penaeus monodon. Frequency (number and \%) of association of WSSV Indel-I and Indel-II deletion types with shrimp disease status, farming system and farm location. Pearson's chi-squared test was used to test for significant effects of shrimp sources; ${ }^{\mathrm{ns}} \mathrm{p}>0.05,{ }^{*} \mathrm{p}<0.05,{ }^{* *} \mathrm{p}<0.001$

\begin{tabular}{|c|c|c|}
\hline \multirow{2}{*}{$\begin{array}{l}\text { Shrimp source } \\
\text { Indel-I }\end{array}$} & \multicolumn{2}{|c|}{ Indel deletion length } \\
\hline & $5950 \mathrm{bp}$ & $6031 \mathrm{bp}$ \\
\hline \multicolumn{3}{|l|}{ Farming stage ${ }^{\mathrm{ns}}$} \\
\hline Emergency harvest & $136(96 \%)$ & $5(4 \%)$ \\
\hline Pond stocking & $25(93 \%)$ & $2(7 \%)$ \\
\hline \multicolumn{3}{|l|}{ Farm type $^{\text {ns }}$} \\
\hline Improved-extensive ponds & $43(96 \%)$ & $2(4 \%)$ \\
\hline Semi-intensive ponds & $79(94 \%)$ & $5(6 \%)$ \\
\hline Rice-shrimp plots & $39(100 \%)$ & $0(0 \%)$ \\
\hline \multicolumn{3}{|l|}{ Province $^{* *}$} \\
\hline Ca Mau province & $53(88 \%)$ & $7(12 \%)$ \\
\hline Bac Lieu province & $108(100 \%)$ & $0(0 \%)$ \\
\hline Indel-II & $8539 \mathrm{bp}$ & $\begin{array}{l}10970 \text { to } \\
11866 \mathrm{bp}\end{array}$ \\
\hline \multicolumn{3}{|l|}{ Farming stage ${ }^{*}$} \\
\hline Emergence harvest & $77(48 \%)$ & $82(52 \%)$ \\
\hline Pond stocking & $32(68 \%)$ & $15(32 \%)$ \\
\hline \multicolumn{3}{|l|}{ Farm type $^{* *}$} \\
\hline Improved-extensive ponds & $50(68 \%)$ & $24(32 \%)$ \\
\hline Semi-intensive ponds & $22(23 \%)$ & $73(77 \%)$ \\
\hline Rice-shrimp plots & $37(100 \%)$ & $0(0 \%)$ \\
\hline \multicolumn{3}{|l|}{ Province $^{* *}$} \\
\hline Ca Mau province & $61(76 \%)$ & $19(24 \%)$ \\
\hline Bac Lieu province & $48(38 \%)$ & $78(62 \%)$ \\
\hline
\end{tabular}

farmed across the Mekong Delta (Table 5). It is possible that WSSV strains with this Indel-II deletion type have been transferred from central to southern Vietnam through infected PL. However, based on the limited and fragmented spatiotemporal data on Indel-II, it is equally plausible that WSSV strains with the
8539 bp deletion type have existed in shrimp or other crustaceans in southern Vietnam for some time and have been simply missed until the present, more comprehensive study of $P$. monodon farmed across the Mekong Delta.

On various spatiotemporal scales, Indel-I and Indel-II types have been used to investigate how WSSV might have spread and evolved (Dieu et al. 2004, 2010, Marks et al. 2004, 2005, Pradeep et al. 2008a, Tan et al. 2009, Zwart et al. 2010, Tan \& Shi 2011). While these studies have relied generally on WSSV genotyping data on relatively small numbers of shrimp, often sourced from distant locations, in this study WSSV strains were examined from a large number of shrimp collected over a $3 \mathrm{yr}$ period from many farms widely spread across 2 neighboring provinces in the Mekong Delta. Variations in Indel-I and Indel-II types were limited and stable temporally, suggesting WSSV genotypes predominating in this region could have been determined quite accurately from far fewer samples. However, owing to the large number of samples examined, existing PCR primer sets were used, and based on the finding that these primer sets failed to amplify a product for samples that tested positive in the robust commercial IQ2000 PCR for diagnosing WSSV infection, it is possible that these primer sets limited detections to those Indel-I and Indel-II reported previously.

Univariate tests were undertaken with Indel-I and Indel-II types detected across the limited number of WSSV-infected shrimp that genotyped successfully to identify whether these might correlate with disease status, farming system and farm location. However, as different farming systems predominate in the 2 provinces studied and as emergency harvests owing to WSSV disease occur predominantly at semiintensive farms (Hoa et al. 2011a,b), where most dis- 
eased samples examined in this study originated from, the pertinence of these correlations need to be viewed with caution. Indel-I and Indel-II types segregated based on province, in a way that was similar to that found with Indel-II types of WSSV strains detected in shrimp from northern, central and southern regions of Vietnam (Dieu et al. 2010); although, to be completely consistent with this, only Indel-II variants with larger deletions would have been expected to be detected. Another major limitation of the sample set was that healthy shrimp were collected only as PL or juveniles at pond stocking, and diseased shrimp were collected from emergency harvested ponds. This sampling regime is likely to have biased correlations of disease with Indel-I and Indel-II deletion types, as few diseased shrimp originated from improved-extensive ponds, as shrimp were primarily sampled from these ponds at the time of stocking when they were healthy.

The $10970 \mathrm{bp}$ Indel-II deletion was correlated most strongly with disease, followed by the 8539 bp IndelII deletion, although this deletion type was also detected commonly in healthy PL and juveniles sampled when ponds were stocked. Such correlations concur with previous evidence of specific WSSV genotypes associating with disease (Hoa et al. 2005, Musthaq et al. 2006) and with WSSV strains with shorter genomes being more virulent (Marks et al. 2005, Pradeep et al. 2009, Zwart et al. 2010). However, why WSSV strains with longer Indel-II deletions seem to cause or result from disease remains to be elucidated.

Short Indel-II deletions were found most frequently among WSSV strains detected in healthy shrimp sampled when improved-extensive ponds and riceshrimp plots were stocked. In contrast, longer WSSV Indel-II deletions were found most frequently in healthy shrimp sampled when semi-intensive ponds were stocked. Shrimp continually inhabit improvedextensive ponds that are never drained, and in riceshrimp plots, shrimp are present throughout the dry season. It is possible, therefore, that low virulence WSSV variants can persist in these shrimp populations (Dieu et al. 2011), which might lead to higher frequencies of mixed-genotype infections (Hoa et al. 2011a). In contrast, in semi-intensive farming systems, the high densities of shrimp probably promote transmission, stress and more virulent WSSV variants causing disease outbreaks. Moreover, the relatively short crop durations interspersed by pond draining and cleaning provide no opportunities for shrimp subpopulations to persist, and thus no advantage to WSSV for persisting in such stocks (Dieu et al. 2011). While these factors could explain why more virulent WSSV strains with longer Indel-II deletions and shorter overall genomes (Zwart et al. 2010) were found more frequently in semi-intensive ponds systems, no data were collected on the hatchery sources of $\mathrm{PL}$, which might also influence what genotypes were detected. In any case, our data support those of other studies in which farming practices have been found to influence the risk of disease (Joffre \& Bosma 2009) and what WSSV genotypes exist in the shrimp (Dieu et al. 2011).

Examining WSSV Indel-I and Indel-II types in a large number of healthy and diseased shrimp collected over a 3 yr period from various farm types in 2 provinces in the Mekong Delta found that Indel-I types have little epidemiological value, but longer Indel-II deletions correlated significantly with diseased shrimp that were emergency harvested at semi-intensive farms.

Acknowledgements. The research was funded by the Rebuilding Resilience of Coastal Populations and Aquatic Resources (RESCOPAR) program of Wageningen University. M.P.Z. was supported by a Rubicon Grant from The Netherlands Organization for Scientific Research (NWO; www.nwo.nl). We thank shrimp farmers and extension workers at the sampling sites in Bac Lieu and Ca Mau provinces who supported or assisted in sampling, and Dr. J. Cowley and Mr. H. Muriuki Kariithi for constructive comments on the manuscript.

\section{LITERATURE CITED}

Anonymous (2009) Planning for aquaculture development in the Mekong River Delta to the year 2015 and orientation to 2010. Institute for Fisheries Economic and Planning, Ho Chi Minh City

Chen J (2008) Studies of shrimp white spot syndrome virus by protein array platform and proteomics approaches. $\mathrm{PhD}$ thesis, National University of Singapore

> Chen LL, Wang HC, Huang CJ, Peng SE and others (2002) Transcriptional analysis of the DNA polymerase gene of shrimp white spot syndrome virus. Virology 301:136-147

$>$ Chou HY, Huang CY, Wang CH, Chiang HC, Lo CF (1995) Pathogenicity of a baculovirus infection causing white spot syndrome in cultured penaeid shrimp in Taiwan. Dis Aquat Org 23:165-173

> Dieu BTM, Marks H, Siebenga J, Goldbach R, Zuidema D, Duong TP, Vlak JM (2004) Molecular epidemiology of white spot syndrome virus within Vietnam. J Gen Virol 85:3607-3618

Dieu BTM, Marks H, Zwart MP, Vlak JM (2010) Evaluation of white spot syndrome virus variable DNA loci as molecular markers of virus spread at intermediate spatiotemporal scales. J Gen Virol 91:1164-1172

Dieu BTM, Vlak JM, Zwart MP (2011) Effects of extensive and intensive shrimp farming on the genetic composition of white spot syndrome virus populations. In: BondadReantaso MG, Jones JB, Corsin F, Aoki T (eds) Diseases in Asian aquaculture VII. Asian Fisheries Society, Fish Health Section, Selangor, p 145-156

Escobedo-Bonilla CM, Alday-Sanz V, Wille M, Sorgeloos P, Pensaert MB (2008) A review on the morphology, molec- 
ular characterization, morphogenesis and pathogenesis of white spot syndrome virus. J Fish Dis 31:1-18

$>$ Flegel TW (1997) Major viral diseases of the black tiger prawn (Penaeus monodon) in Thailand. World J Microbiol Biotechnol 13:433-442

Hall TA (1999) BioEdit: a user-friendly biological sequence alignment editor and analysis program for Windows 95/98/NT. Nucleic Acids Symp Ser 41:95-98

Han F, Xu J, Zhang X (2007) Characterization of an early gene (wsv477) from white spot syndrome virus (WSSV). Virus Genes 34:193-198

Hoa TTT, Hodgson RA, Oanh DT, Phuong NT, Preston NJ, Walker PJ (2005) Genotypic variations in tandem repeat DNA segments between ribonucleotide reductase subunit genes of white spot syndrome virus (WSSV) isolates from Vietnam. In: Walker PJ, Lester RG, Bondad-Reantaso MG (eds) Diseases in Asian aquaculture V. Asian Fisheries Society, Fish Health Section, Manila, p 339-351

Hoa TTT, Zwart MP, Phuong NT, Oanh DTH, de Jong MCM, Vlak JM (2011a) Mixed-genotype WSSV infections of shrimp are inversely correlated with disease outbreaks in ponds. J Gen Virol 92:675-680

> Hoa TTT, Zwart MP, Phuong NT, Vlak JM, de Jong MCM (2011b) Transmission of white spot syndrome virus in improved-extensive and semi-intensive shrimp production systems: a molecular epidemiology study. Aquaculture 313:7-14

Hoa TTT, Zwart MP, Phuong NT, de Jong MCM, Vlak JM (2012) Low numbers of repeat units in VNTR regions of White spot syndrome virus are correlated with disease outbreaks. J Fish Dis (in press)

Huang J, Song XL, Yu J, Yang CH (1995) Baculoviral hypodermal and hematopoietic necrosis-study on the pathogen and pathology of the explosive epidemic disease of shrimp. Mar Fish Res 16:1-10 (in chinese)

> Inouye K, Miwa S, Oseko N, Nakano H, Kimura T, Momoyama K, Hiraoka M (1994) Mass mortality of cultured kuruma shrimp Penaeus japonicus in Japan in 1993: electron microscopic evidence of the causative virus. Fish Pathol 29:149-158

Joffre OM, Bosma RG (2009) Typology of shrimp farming in Bac Lieu Province, Mekong Delta, using multivariate statistics. Agric Ecosyst Environ 132:153-159

Kim CK, Kim PK, Sohn SG, Sim DS and others (1998) Development of a polymerase chain reaction (PCR) procedure for the detection of baculovirus associated with White Spot Syndrome (WSBV) in penaeid shrimp. J Fish Dis 21: $11-17$

Lan Y, Lu W, Xu X (2002) Genomic instability of prawn white spot bacilliform virus (WSBV) and its association to virus virulence. Virus Res 90:269-274

Leu JH, Yang F, Zhang X, Xu X, Kou GH, Lo CF (2009) Whispovirus. Curr Top Microbiol Immunol 328:197-227

Lightner DV (2011) Virus diseases of farmed shrimp in the Western Hemisphere (the Americas): a review. J Invertebr Pathol 106:110-130

Marks H, Goldbach RW, Vlak JM, van Hulten MCW (2004) Genetic variation among isolates of white spot syndrome virus. Arch Virol 149:673-697

Marks H, van Duijse JJA, Zuidema D, van Hulten MCW, Vlak JM (2005) Fitness and virulence of an ancestral white spot syndrome virus isolate from shrimp. Virus Res 110:9-20

Muller IC, Andrade TP, Tang-Nelson KF, Marques MR, Lightner DV (2010) Genotyping of white spot syndrome virus (WSSV) geographical isolates from Brazil and comparison to other isolates from the Americas. Dis Aquat Org 88:91-98

Musthaq SS, Sudhakaran R, Ahmed IVP, Balasubramanian G, Hameed SAS (2006) Variability in the tandem repetitive DNA sequence of white spot syndrome virus (WSSV) genome and stability of VP28 gene to detect different isolates of WSSV from India. Aquaculture 256:34-41

Nadala ECB Jr, Loh PC (1998) A comparative study of three different isolates of white spot virus. Dis Aquat Org 33: 231-234

OIE (Office International des Epizooties/World Animal Health Organization) (2009) Manual of diagnostic tests for aquatic animals. OIE, Paris

> Pradeep B, Shekar M, Karunasagar I, Karunasagar I (2008a) Characterization of variable genomic regions of Indian white spot syndrome virus. Virology 376:24-30

Pradeep B, Shekar M, Gudkovs N, Karunasagar I, Karunasagar I (2008b) Genotyping of white spot syndrome virus prevalent in shrimp farms of India. Dis Aquat Org 78:189-198

> Pradeep B, Karunasagar I, Karunasagar I (2009) Fitness and virulence of different strains of white spot syndrome virus. J Fish Dis 32:801-805

Shekar M, Karunasagar I, Karunasagar I (2005) A computer based identification of variable number tandem repeats in white spot syndrome virus genomes. Curr Sci 89:882-887

Tan Y, Shi Z (2011) Genotyping of white spot syndrome virus in Chinese cultured shrimp during 1998-1999. Virol Sin 26:123-130

Tan Y, Xing Y, Zhang H, Feng Y, Zhou Y, Shi ZL (2009) Molecular detection of three shrimp viruses and genetic variation of white spot syndrome virus in Hainan Province, China, in 2007. J Fish Dis 32:777-784

Tsai JM, Wang HC, Leu JH, Hsiao HH, Wang AHJ, Kou GH, Lo CF (2004) Genomic and proteomic analysis of thirtynine structural proteins of shrimp white spot syndrome virus. J Virol 78:11360-11370

van Hulten MCW, Witteveldt J, Peters S, Kloosterboer N and others (2001) The white spot syndrome virus DNA genome sequence. Virology 286:7-22

Walker PJ, Gudkovs N, Mohan CV, Raj VS and others (2011) Longitudinal disease studies in small-holder black tiger shrimp (Penaeus monodon) ponds in Andhra Pradesh, India. II. Multiple WSSV genotypes associated with disease outbreaks in ponds seeded with uninfected postlarvae. Aquaculture 319:18-24

> Wang YG, Hassan MD, Shariff M, Zamri SM, Chen X (1999) Histopathology and cytopathology of white spot syndrome virus (WSSV) in cultured Penaeus monodon from peninsular Malaysia with emphasis on pathogenesis and the mechanism of white spot formation. Dis Aquat Org 39:1-11

Wongteerasupaya C, Pungchai P, Withyachumnarnkul B, Boonsaeng V, Panyim S, Flegel TW, Walker PJ (2003) High variation in repetitive DNA fragment length for white spot syndrome virus (WSSV) isolates in Thailand. Dis Aquat Org 54:253-257

Yang F, He J, Lin X, Li Q, Pan D, Zhang X, Xu X (2001) Complete genome sequence of the shrimp white spot bacilliform virus. J Virol 75:11811-11820

Zwart MP, Dieu BTM, Hemerik L, Vlak JM (2010) Evolutionary trajectory of white spot syndrome virus (WSSV) genome shrinkage during spread in Asia. PLoS ONE 5: e13400 